\title{
How student teachers understand African philosophy
}

\author{
Authors: \\ Matsephe M. Letseka ${ }^{1}$ \\ Elza Venter ${ }^{2}$ \\ Affiliations: \\ ${ }^{1}$ Department of Educational \\ Studies, University of South \\ Africa, South Africa \\ ${ }^{2}$ Department of Teacher \\ Education, University of \\ South Africa, South Africa \\ Correspondence to: \\ Matsephe Letseka \\ Email: \\ letsemm@unisa.ac.za

\section{Postal address:} \\ PO Box 392, University \\ of South Africa, 0003, \\ South Africa

\section{Dates:} \\ Received: 05 July 2011 \\ Accepted: 29 Sept. 2011 \\ Published: 12 Nov. 2012 \\ How to cite this article: \\ Letseka, M.M. \& Venter, \\ E., 2012, 'How student \\ teachers understand African \\ philosophy', Koers - Bulletin \\ for Christian Scholarship \\ 77(1), Art. \#25, 8 pages. \\ http://dx.doi.org/10.4102/ \\ koers.v77i1.25

\section{Note:} \\ This article was developed \\ from a paper delivered at \\ the Koers-75 Conference on \\ 'Worldview and Education', \\ held in Potchefstroom, South \\ Africa, from 30 May to 02 \\ June 2011. \\ Hierdie artikel is ' $n$ verdere \\ ontwikkeling van ' $n$ \\ voordrag gelewer by die \\ Koers-75 Konferensie oor \\ 'Worldview and Education' in \\ Potchefstroom, Suid-Afrika, \\ vanaf 30 Mei tot 02 Junie 2011.
}

(C) 2012. The Authors. Licensee: AOSIS OpenJournals. This work is licensed under the Creative Commons Attribution License.
The question 'What constitutes African philosophy?' was first raised with the publication of Placide Tempels's seminal work Bantu philosophy in 1959. Tempels's book inevitably elicited considerable critical response from African philosophers, which culminated in a wide range of publications such as Wiredu's (1980) Philosophy and an African culture, Hountondji's (1983) African philosophy: Myth and reality, Oruka's (1990) Sage philosophy: Indigenous thinkers and modern debate on African philosophy, Shutte's (1993) Philosophy for Africa, Masolo's (1994) African philosophy in search of identity and Gyekye's (1995) An essay of African philosophical thought: The Akan conceptual scheme. It has been over 60 years since the publication of Tempels's book and there continues to be serious debate about African philosophy. This article sought to contribute to the debate on the various conceptions of African philosophy, but with a focus on the challenges of teaching African philosophy to Philosophy of Education students at an open distance learning institution in South Africa. This article discussed the tendency amongst undergraduate Philosophy of Education students to conflate and reduce African philosophy to African cultures and traditions, and to the notion of $u b u n t u$, and sought to understand the reasons for students' inclination to treat African philosophy in this way. It examined students' background knowledge of African philosophy, their critical thinking skills and whether their official study materials are selected and packaged in a manner that, in fact, adds to the challenges they face. Finally, the article explored the ways in which Philosophy of Education lecturers can adapt their pedagogy to provide students with a better understanding of African philosophy.

Hoe student-onderwysers Afrika-filosofie verstaan. Die vraag 'Wat behels Afrika-filosofie?' was vir die eerste keer ge-opper met die publikasie van Placide Tempels se werk Bantu Philosophy in 1959. Dit was onvermydelik dat Tempels se boek 'n groot hoeveelheid kritiek uitgelok het van Afrika-filosowe, wat uitgeloop het op ' $n$ wye reeks publikasies, soos: Wiredu (1980) Philosophy and an African Culture; Hountondji (1983) African Philosophy: Myth and Reality; Oruka (1990) Sage Philosophy: Indigenous thinkers and modern debate on African philosophy; Shutte (1993) Philosophy for Africa; Masolo (1994) African Philosophy in Search of Identity; en Gyekye (1995) An Essay of African Philosophical Thought: The Akan Conceptual Scheme. Sestig jaar sedert die publikasie van Tempels se boek is daar steeds ernstige gesprekke rondom Afrika-filosofie. Hierdie artikel wil bydra tot die debat rondom die begrip van Afrika-filosofie, maar met die klem op die uitdagings om Afrika-filosofie aan Filosofie van die Opvoeding studente aan 'n oop afstandsonderrig-instituut in Suid-Afrika te onderrig. Die artikel worstel met die neiging van voorgraadse studente van Filosofie van die Opvoeding om Afrika-filosofie te reduseer tot Afrika kulture en tradisies, asook die idee van $u b u n t u$. Die artikel probeer om te verstaan waarom studente Afrika-filosofie op dié wyse hanteer. Daar word gekyk na die studente se agtergrondkennis van Afrika-filosofie, hulle kritiese denkvaardigheid en of die amptelike studiemateriaal dalk op wyse geselekteer en bymekaar gevoeg word wat kan bydra tot die uitdagings wat studente in die gesig staar. In die laaste instansie eksploreer die navorsers maniere waarop dosente van Filosofie van die Opvoeding hul pedagogie kan aanpas om studente te help om Afrika-filosofie beter te kan verstaan.

\section{Introduction}

This article draws on a study based on five years of involvement in an undergraduate Philosophy of Education module at an open distance learning (ODL) institution in South Africa. One specific assignment question in the module requires students to draw on African philosophy to solve practical classroom or school problems and to discuss the advantages and disadvantages of using African philosophy. In their responses, the majority of the students tended to reduce African philosophy to traditions and cultural practices in African communities, or to equate African 
philosophy with ubuntu. This kind of thinking is highly dubious. Firstly, African philosophy is much broader and more complex than the traditions and cultural practices of African communities. Secondly, ubuntu is only a worldview within African philosophy and therefore cannot, on its own, be regarded as a philosophy. The students also tended simply to reproduce the information in their textbooks in answering the question without any critical analysis.

The researchers and authors accept the work of Kenyan philosopher, H. Odera Oruka (2002), as the foundation in understanding African philosophy. He formulated the four trends of African philosophy - ethno-philosophy, philosophic sagacity or sage philosophy, nationalistideological philosophy and critical or professional philosophy. The researchers argue that the works of Oruka, as well as Kenyan philosopher, John S. Mbiti, ought to be the basis for attempts to understand African philosophy. Ubuntu and communalism are discussed as components underlying all strands of African philosophy.

In this article, the authors attempt to clarify the notions of African philosophy and critical thinking in African philosophy. They also discuss the lack of critical thinking skills of students in general. They recommend ways of teaching students the principles of thinking critically about the study materials they receive for a course in African philosophy, as well as how to think analytically before answering assignment questions. The research was conducted through a literature review and document analysis using student assignment answers. It was also approached from an analytical research design point of view, where concepts are investigated through an analysis of documents (McMillan \& Schuhmacher 2010:24).

\section{What is African philosophy?}

For Heidegger (1956), the word 'philosophy' is derived from the Greek 'philosophia', which means 'path'. He argues that 'philosophia' suggests the innermost basic feature of the Western-European history. This is echoed by Priest (2006:203), who regards philosophers as having the responsibility 'for creating new ideas, systems of thought, pictures of the world and its features'. Priest (2006:201) argues that 'learning philosophy is not simply learning a bunch of facts; it is learning how critically to evaluate people's ideas, including ... one's own ideas and those of one's teachers'. In turn, Letseka (2000) argues:

\begin{abstract}
... all people have a philosophy that guides the way they live, their perceptions of otherness, and the decisions and choices they make about every aspect of their lives' and that 'such a philosophy often stands out among other philosophies as a distinct set of beliefs and values with which such people identify. (p. 179)
\end{abstract}

For a long time, the idea of an African philosophy was frowned upon. Any discussions on African philosophy revolved around whether or not there was such a thing and, if so, what it was (Bodunrin 1981:161). Gratton (2003:61) argues that the very term 'African philosophy' was controversial and, for a long time, Western philosophers such as Kant and Hegel concluded that 'Africans did not and could not have a philosophy'.
For the authors, a good starting point in conceptualising African philosophy is Mbiti's seminal works, African religions and philosophy (1969) and Introduction to African religion (1975). Mbiti underscores African community and its communal nature, which is marked by communal interdependence. In traditional African life, the individual owes their existence to other people, including those of past generations and their contemporaries. The individual cannot therefore exist alone. They are simply part of the whole. Hence the saying:

Whatever happens to the individual happens to the whole group, and whatever happens to the whole group happens to the individual. The individual can only say: I am, because we are; and since we are, therefore I am. (Mbiti 1969:108-109)

Oruka (2002:120-124) demarcates African philosophy into ethno-philosophy, philosophic sagacity, nationalist-ideological philosophy and critical or professional philosophy. Ethnophilosophy is embodied in communal African customs, poems, taboos, religions, songs and dances, the result being that African philosophy is identified with communal or 'folk philosophy' (Oruka 2002:121). Philosophic sagacity is practiced by indigenous thinkers or sages. These are people who have not had the benefit of modern education but are considered critical independent thinkers capable of using their own thought and judgements based on the power of reason and inborn insight rather than on the authority of the communal consensus (Oruka 2002:121). Philosophic sagacity is individualistic, dialectical, rigorous and philosophical in the strict sense (Oruka 2002:122). Nationalist-ideological philosophy advocates the revival of the cardinal ethical principle of traditional humanist African communalism (Oruka 2002:122). Nationalist-ideological philosophers include African leaders such as Amilca Cabral of Guinea Bissau, Kwame Nkrumah of Ghana and Julius Nyerere of Tanzania (Higgs \& Smith 2006:91). Critical or professional philosophy is practiced by professional philosophers who are trained in Western philosophy and conceive philosophy as a universal discipline, the meaning of which cannot depend on racial or regional make-up.

These are the main ideas the authors ascribe to African philosophy; however, there are a few components underlying all African philosophical thinking, namely ubuntu and communalism.

\section{Ubuntu}

Broodryk (2002:13) defines ubuntu as a comprehensive ancient African worldview based on the values of intense humanness, caring, sharing, respect, compassion and associated values. Similarly, Letseka (2000:180) argues that ubuntu has normative implications in that it encapsulates moral norms and values such as 'altruism, kindness, generosity, compassion, benevolence, courtesy, and respect and concern for others'.

Amongst Southern African communities, ubuntu is associated with the maxim umuntu ngumuntu ngabantu, which, loosely translated into English, means that to be a human being is to affirm one's humanity by recognising the humanity of 
others and, on that basis, establish humane relations with them (Ramose 2002; Ramphele 2001). Sindane (1994:8-9) underscores the point that, ... ubuntu inspires us to expose ourselves to others, to encounter the difference of their humanness so as to inform and enrich our own'. Letseka (2000:183) argues that the concept of ubuntu illuminates the communal embeddedness and connectedness of a person to other persons and highlights the importance attached to people and to human relationships.

\section{Communalism}

Communal interdependence is premised on the existence and flourishing of the extended family. In traditional African life, an individual lives in or is part of a family; that is, part of an extended family (Mbiti 1975:176). Ayisi (1992:16) contends that the extended family 'forms the raison d'etre of all social co-operation and responsibility. It acts as a social security for the members of the group'. For Mbiti (1975:176), the extended family is a microcosm of the wider society. It presupposes a broad spectrum of associations including children, parents, grandparents, uncles, aunts, cousins, nieces and other distant relatives. Gyekye (1997) concurs:

one outstanding cultural value of the traditional African society that is a feature of ever-present consciousness of ties of kinship is the emphasis on the importance of the family - the extended family. (pp. 292-293)

In some societies, it is normal for children to be sent to live with relatives for months or even years as part of these families (Mbiti 1969:106). Venter (2004:151) argues that communalism is an awareness of the fundamental interdependence of people, whereby duty to one's social group is more important than individual rights and privileges. Letseka (2000:181) emphasises that belonging to a community constitutes the very fabric of African life. In this respect, African philosophy should:

... speculate about the communality of the individual in the African setting. It should provide conceptual frameworks for interpreting and analysing the humaneness that botho and ubuntu capture. It should provide rational tools for critical reflections on personal wellbeing or human flourishing, on communal ethics and how these ought to impact on human conduct. (Letseka 2000:182)

Another contested perception that critics of African philosophy often have, is that African people cannot think critically.

\section{Critical thinking in African philosophy}

One criticism of African philosophy is that it lacks reason and rationality, which are key aspects of critical thinking. However, as Senghor (1976:33-34) points out, reason is a universal human trait and the greatest disservice to African philosophy is to deny it reason and dress it in magic and extra-rational traditional reason. Reason seems to be an integral aspect of critical thinking. Waghid (2004) argues:

African philosophy accentuates the importance of being reasonable - the ability of people to articulate clear, logical and defensible arguments, on the one hand and to demonstrate a willingness to listen carefully to others, on the other hand. (p. 57)
Bodunrin (1981:162) concurs that, 'in Africa there are critical independent thinkers who guide their thought and judgements by the power of reason and insight rather than by authority of the communal consensus'.

\section{Importance of critical thinking}

We found the most appropriate conceptions of critical thinking to be those of Beyers (1988) and Ennis (1964, 1989). Ennis $(1964: 599,1989: 4)$ defines critical thinking as 'the correct way of assessing statements' and 'reasonable reflective thinking focused on deciding what to believe or do', whilst Beyers (1988:61) contends that critical thinking consists essentially of judging the authenticity, worth or accuracy of something; that is, it is essentially evaluative. It involves precise, persistent and objective analysis of any claim, source or belief to judge its accuracy, validity or worth. Beyers (1988:62) argues that probably the most all-inclusive act of critical thinking is that of argumentation - argument making and argument analysing. An argument, in critical thinking terms, is an assertion or claim accompanied by a line of reasoning that supports this claim and that denies any alternative claim.

This article grapples with the tendency amongst student teachers of Philosophy of Education to conflate and reduce African philosophy to African cultures and traditions, as well as to the notion of ubuntu. Students also seem to think that African philosophers cannot think critically. The researchers examined students' knowledge of African philosophy and their critical thinking skills by using a qualitative research design with document analysis.

\section{Research method and design}

This article draws on a qualitative conceptual study that employs philosophical inquiry and document or content analysis. Nieuwenhuis (2010:51) argues that qualitative research methodology is 'concerned with understanding the processes and the social and cultural contexts which underlie various behavioural patterns and is mostly concerned with exploring the "why" questions of the research'. Patton (2002:39) describes qualitative research as research that 'takes place in real-world settings and the researcher does not attempt to manipulate the phenomenon of interest'. Thus, a qualitative conceptual study engages critically with understanding concepts and aims to add to our existing body of knowledge and understanding. Conceptual studies are also abstract and philosophical in nature and employ critical analysis of literature, especially where concepts need to be explained and clarified (Nieuwenhuis 2010:72).

This article is conceptual and analytical and employs research methods typically used in conceptual studies, such as a literature review, philosophical inquiry, as well as document or content analysis (Nieuwenhuis 2010:71). The written assignments of undergraduate students of Philosophy of Education are the documents that were critiqued and analysed using philosophical inquiry. Additional secondary sources such as books, journal articles, conference papers, 
reports on African philosophy, as well as South African education policy documents and legislation were also consulted to provide a nuanced analysis of the assignments.

\section{Philosophical inquiry}

The function of philosophy is entirely critical (Ayer 1972:65). It tests the validity of scientific hypotheses and everyday assumptions. Morrow (1989:xiii) argues that Philosophy of Education is a theoretical discipline which has as its aim the critical investigation of forms of understanding relevant to education. It is concerned with issues which are of profound importance to everyone, not only to professional philosophers of education. It is an aspect of public critical debate on education and schooling in society. Ellis (1983:212) posits that philosophical inquiry involves using intellectual analysis to clarify meanings, make values manifest, identify ethics and study the nature of knowledge. Moreover, 'philosophic inquiry is used to expose, clarify, and articulate perspectives, beliefs, conceptualisations and methods that characterise a field' (Ellis 1983:212). Burns and Grove (2001:616) suggest that the data for most philosophical studies are written materials. In this study, we critically analysed students' written assignments. Because these assignments were essentially educational documents, the analysis is philosophical rather than empirical (Pring 2007:315).

Philosophical inquiry is therefore pertinent to this article as a method of research in that it is an analytical tool of Philosophy of Education. It deals with educational as well as philosophical issues. Document analysis was used specifically to analyse the assignments. The assignments were treated as expressive and projective personal documents (Allport 2006:4). It can therefore be argued that this article resides in the domain of Philosophy of Education. It contains a philosophical inquiry into the assumptions about African philosophy by Philosophy of Education students at an ODL institution in South Africa.

\section{Document or content analysis}

According to Ary et al. (2006:464), document analysis is 'research applied to written or visual materials for the purpose of identifying specified characteristics of the material' and for the purpose of discovering the relative importance of, or interest in, certain topics. Although the sources of document study are usually personal documents such as autobiographies, diaries and letters, this research treats the students' assignments as personal documents in the category of expressive and projective documents. These include compositions or assignments, which are usually written in the first person (Allport 2006:3-4). For Gall, Bog and Gall (1996:356), document analysis can also be carried out on written documents such as textbooks, students' completed homework, assignments and tests, computer printouts of school data, newspapers and memoranda.

Document study has a close affinity to content analysis in that the document being studied contains the content to be analysed. According to Holsti (1969:2), content analysis is a multipurposed research method developed specifically for investigating any problem in which the content of communication is the basis of inference. In the same breath, Thomas (1998:118) states that content analysis entails searching through one or more documents to answer questions that the investigator brings to the search.

\section{Extended literature review}

According to Hofstee (2006:121), an extended literature review is a research method 'undertaken to provide an overview of the scholarship in a particular aspect of a field, or of a field in its entirety'. Literature reviews cannot be used on their own because they cannot produce any new knowledge. Their purpose is to provide a new perspective on what has gone before. For Neuman (2006:111), a literature review is based on the fact that knowledge is always growing and people learn from and build on what others have done before.

\section{Sample selection}

The population of this study comprised undergraduate student teachers registered for the course in Philosophy of Education. Researchers are rarely able to investigate an entire population of individuals who interest them so they have to select a study sample of individuals, which in qualitative research is usually small (Gall et al. 1996:215, 217). This sample has to allow the researchers to 'develop a deeper understanding of the phenomena being studied' (Gall et al. 1996:217). With this in mind, the researchers selected 60 student assignments on which to base their analysis.

Purposeful sampling was deemed the most suitable for this study. The researchers purposefully selected the assignments that evidenced undergraduate students' particular perception of African philosophy. As Patton (2002:230) points out, 'the logic and power of purposeful sampling lie in selecting informationrich cases for study in depth'. The sampled assignments showed that Philosophy of Education undergraduate student teachers had a flawed perception of African philosophy, either owing to their poor critical thinking skills or to an ambiguous articulation of African philosophy in some of their learning support material.

\section{Ethical considerations}

The researchers undertook to comply with the research principles of 'respect for persons', 'beneficence', 'justice', 'confidentiality', 'non-disclosure', 'voluntary participation' and 'informed consent'. These principles require researchers to be sensitive in their relations with their research subjects, to treat research subjects with respect and dignity, to be explicit about their assumptions and intentions, to provide guarantees of confidentiality and non-disclosure and to seek research subjects' informed consent to participate voluntarily in the study. The students whose assignments were used were informed and their written permission sought. They were assured that their names or identities would not be 
disclosed. Only the information from their scripts would be used in compliance with the ethical principles of anonymity and non-disclosure.

\section{Findings}

This section examines the findings on undergraduate students' perceptions and misperceptions in respect of African philosophy. These findings are drawn from the students' responses to the assignment questions and the contents of the African philosophy chapter in their prescribed textbook.

\section{Conflation of African philosophy with ubuntu}

The tendency to conflate African philosophy with ubuntu was evident in the responses of the majority of the students, as they were not able to differentiate between African philosophy and ubuntu. Below are some of the original, unedited responses given by students who regarded $u b u n t u$ as an African philosophy:

'African philosophy is $u b u n t u$ the Zulu word from traditional African philosophy that encourage people to live and work together'.

'African philosophy which is $u b u n t u$ is an African philosophy which embraces the notion of humanity to other'.

Below is the case of a student who used the concepts of African philosophy and ubuntu interchangeably. The four methods mentioned are in fact the four trends in African philosophy as formulated by H. Odera Oruka; ubuntu does not offer any methods of inquiry:

'In African philosophy, ubuntuism is the central idea and was formed by using the four methods of enquiry. These methods are: ethnic, sage, political and pure philosophy'.

The above student failed to mention African philosophy anywhere further in the essay. Even the advantages and the disadvantages of African philosophy were attributed to ubuntu. The disadvantages discussed below are those attributed to African philosophy in the students' reading material, not to ubuntu:

'There are a few things with ubuntuism, however. One being that it doesn't see females as the equivalent of males ... Another area in which ubuntuism falls short is that it doesn't allow for critical thinking'.

Some students treated African philosophy as if it is part of ubuntu, instead of the other way round:

'The advantages of African philosophy is that it is rooted in ubuntuism that means it is related to human values'.

'According to Higgs \& Smith, African philosophy is based on the concept of "ubuntu", which means "humanity" and "I am because you are"'.

In their chapter on African philosophy, Higgs and Smith (2006:47) indicate that ubuntu is 'a central ethical idea of African thought', but not African thought in itself. As Sindane and Liebenberg (2000:38) argue, even though ubuntu is often seen as a purely (South) African concept, it is not, because every people or community has its own version of $u b u n t u$.
It can therefore reasonably be argued that African philosophy is not ubuntu and, in the same breath, that ubuntu is not African philosophy. We should underscore in our teaching of African philosophy that ubuntu is only a worldview within African philosophy. However, as the excerpts above indicate, students seem not to differentiate between the two concepts. They either use the two concepts interchangeably or attribute the characteristics of one to the other. Another glaring shortcoming of these students is that in their discussion of African philosophy, they only mention Oruka's four trends of African philosophy in passing and devote most of the discussion to ubuntu. It seems to them that ubuntu is the only, or the most important aspect of African philosophy. This diminishes the significance of aspects such as sage philosophy, political philosophy, pure philosophy and ethno-philosophy. Discussing these trends in detail would indicate to the students that even though their prescribed textbook does not mention it, ubuntu is only part of ethno-philosophy.

\section{Conflation of African philosophy with African traditions and culture}

Oruka's (2002:120-124) four trends of African philosophy make it clear that there is more to African philosophy than just traditions and culture, which would be represented by ethno-philosophy. Yet, most students fail to acknowledge the other three trends, namely sage philosophy, political philosophy and pure philosophy. Most students conclude that African philosophy relies on culture and traditions. Below are unedited examples of students' responses on the disadvantages of using African philosophy:

'... the disadvantages being ... it [African philosophy] relies on the majority of tradition and partly religion'.

'African philosophy tolerates cruel superstitious practices'.

The fact that African philosophy relies on traditions should not be viewed as a disadvantage. As Bodunrin (1981:171) points out, 'there is no a priori reason why proverbs, myths of gods and angels [and] social practices ... could not be proper subjects for philosophical enquiry'.

Some student teachers believe that their learners will not adopt African philosophy principles because it is not part of their culture, whilst others think that African philosophy will appeal to their learners because it is in their culture. What follows are some of the unedited disadvantages of African philosophy that the students mentioned:

'Some learners may feel that they do not need to adopt ubuntuism because it is not part of their culture'.

'The problem is not about African people living like white people but it is the fact that the more westernised they become, the further behind they are leaving their spirituality, culture, tradition ... The only solution to this problem is that Africans should constantly remember their roots and realise how other cultures admire their spirituality and their traditions'.

In discussing African philosophy, the students tended to concentrate on ethno-philosophy, which comprises communal African traditions, rituals and cultural practices such as 
poems, taboos, religions, songs and dances, and ignored the other trends as advocated by Oruka. As much as myths, folklore and folk wisdom are important in preserving and championing aspects of tradition and as such should be integral to what constitutes African philosophy, other trends such as philosophic sagacity, nationalist-ideological philosophy and critical or professional philosophy are equally critical to an understanding of African philosophy. Giving prominence solely to ethno-philosophy devalues the other trends.

\section{The misconception that African philosophy lacks the element of critical thinking}

From their responses, it seems that most students agree with the authors of their prescribed textbook with regard to African philosophy lacking an element of critical thinking. The students whose assignments were analysed seemed to miss the link between African philosophy and critical thinking. They appeared to take what they read as the absolute truth. In the conclusion of their assignment, the students were required to discuss the advantages and disadvantages of using African philosophy to help them solve a problem of their choice. The advantages were to be properly linked to the solution. However, the disadvantages contradicted the advantages they had already mentioned in their discussions of the solution. One example of this kind of thinking is that of a student who wrote that African philosophy:

'is about wisdom and recognising people who are wise and far sighted and who can think critically'.

Yet, the same student went on to conclude that one of the disadvantages of African philosophy is that:

'if the Nduna or Nkosi would make a community decision about the child, she couldn't be challenged, as African philosophy does not encourage critical thinking'.

Most students cited the above as a disadvantage of African philosophy, even though they mentioned the sages as wise and far-sighted individuals who could think critically. Another original, unedited example would be one student's assertion that:

'it [African philosophy] doesn't help critical thinking. It doesn't challenge power structures as it set out to be'.

Yet, earlier in the essay, the same student made the following case regarding the sages:

'African philosophy is divided into four headings. They comprise of Ethnic philosophy ... Sage philosophy, which deals with the wise ....'

Students cited all these perceived disadvantages from their prescribed textbook without challenging them or relating them to the problem they were trying to solve. This appears to be evidence that the undergraduate students do not apply any critical thinking skills when answering questions. They simply regurgitate what is in their textbook.

\section{Students' lack of critical thinking skills}

From the previous discussions, it is evident that there is a lack of critical thinking amongst Philosophy of Education students in an ODL institution. For instance, students accept uncritically the following controversial disadvantages of African philosophy, as proposed by Higgs and Smith (2006:49), 'It [African philosophy] does not challenge power structures ... It tends to ignore the needs of the individual ... It tolerates cruel superstitious practices (e.g. burning of witches)'. The excerpts quoted above suggest that the cohort of students whose assignments were analysed did not critically interrogate these claims.

An emergent trend amongst undergraduate Philosophy of Education students, which is also evident in the responses to assignments analysed above, is the regurgitation of the information they have read from their prescribed textbooks. This can be attributed to their lack of preparedness for the complexities of university study. Slonimsky and Shalem (2006:46-47) argue that students who have matriculated are generally expected to be highly practised in working in text-based realities and creating text-based realities through writing, but a significant proportion of students enrolling in universities do not appear to have mastered this skill. On the contrary, they tend to follow a series of pervasive patterns in their approach to texts and epistemic practices when they first engage in university study. They have a tendency to reproduce texts verbatim or plagiarise, to focus on examples rather than on principles and to write from a highly subjective viewpoint. They also lack the ability to pull arguments out of the text or cast arguments to include anecdotes as a justification for claims, or to be prescriptive or normative when asked to be analytic.

This lack of preparedness for university study is confirmed by educationists and researchers such as Nyamapfene and Letseka (1995:159-167), who argue that most first-year university students lack the necessary knowledge base required for university learning and teaching. Nyamapfene and Letseka (1995:190) attribute this to a failure to understand concepts and principles. They argue that in order to understand concepts and principles, students need to (1) have good communication skills that will enable them to say and write what they mean, (2) hear what is said and what is hidden, (3) defend their points of view, (4) argue, persuade, negotiate, create, reflect, invent and explore personal, structural and political relationships, (5) speak, read and write with confidence and (6) make their voices heard.

\section{Recommendations}

The researchers would like to argue for the incorporation of the ethical principle ubuntu into the South African school curriculum. This is because ubuntu has the potential to instil values such as tolerance, democracy, communalism, non-sexism and non-racism, which are enshrined in the country's constitution and espoused by the Department of Education (DoE). From an early age, school children should be familiarised with African values such as ubuntu and communalism. This will ensure that when they enter institutions of higher learning, they will be able to engage in discussions of these values in a critical and meaningful way. 
South Africa's education policies make a strong case for the promotion of critical thinking in classroom teaching; yet, large numbers of teachers in the system are not trained to promote critical thinking skills. The researchers recommend the introduction of short courses on critical thinking and African philosophy as in-service training for teachers. Secondly, the introduction of 'philosophy for children' otherwise known as 'P4C' amongst Philosophy of Education scholars is recommended. There is a case to be made that children can be taught and can comprehend philosophical nuances if these are introduced at appropriate levels.

In higher education, African philosophy is studied as part of Philosophy of Education. However, this seems inadequate to instil fully the values which the Department of Education wants implemented in education. The values which are entrenched in the country's constitution are 'democracy, social justice and equity, equality, non-racism and non-sexism, ubuntu (human dignity), an open society, accountability, the rule of law, respect and reconciliation' (DoE 2001:12). The study of African philosophy should enable students to embrace the abovementioned values and put them into practice.

Morrow (2007:19) envisions an ideal teaching situation as one that is characterised by a teacher-student ratio of about 1:15, with plenty of rich face-to-face discussion and the detailed marking of students' scripts. He argues that any departure from this ideal is a deficient and degenerate version of teaching. In large class teaching, which is a typical experience in most schools and in ODL institutions, the ratio is much larger, which makes good teaching with meaningful discussions nearly impossible. It is Morrow's (2007:19) view that the teacher's job is to give learners access to knowledge, hence 'epistemological access'. When students suffer from lack of 'epistemological access', the consequence is that they carry a number of learning deficiencies with them, some of which are described lucidly by Slonimsky and Shalem (2006). It is reasonable to argue that such students would be deficient in a critical-thinking disposition. It follows that the Philosophy of Education students whose assignments are the subject of this study lack this kind of critical thinking. The infusion of critical thinking into higher education teaching and learning in South Africa, especially in the teaching and learning of African philosophy, is recommended.

\section{Conclusion}

In this article, the authors have highlighted the extent to which undergraduate student teachers' understanding of African philosophy is marred by conflations and an inability to apply critical thinking skills. The authors have attempted an articulation of what defines African philosophy. Contrary to the commonly held belief that Africa has no philosophy and that Africans cannot philosophise, they argued that the opposite is the case. The authors have shown that student teachers conflate African philosophy with ubuntu and African traditions and culture. They also identified a misconception amongst students that African philosophy lacks critical thinking. The authors' viewpoint is that this misconception is a result of the students' own lack of critical thinking skills.
Each of Odera Oruka's trends offers some of the definable characteristics of philosophy. Therefore, the researchers made a case for the teaching of African philosophy and the incorporation of $u b u n t u$ and communalism into the education system of South Africa.

\section{Acknowledgements}

I am grateful to my Doctoral promoter and co-author Professor Elza Venter for her guidance and support during my study. I am also grateful for the financial support and access to the library material I received from the University of South Africa.

\section{Competing interests}

The authors declare that they have no financial or personal relationships which may have inappropriately influenced them in writing this article.

\section{Authors' contributions}

M.M.L. (University of South Africa) was the Doctoral student and author of the thesis from which this article is drawn. E.V. (University of South Africa) was M.M.L.'s Doctoral promoter and mentor and co-author of the article.

\section{References}

Allport, G.W., 2006, 'The forms of personal documents', in J. Scott (ed.), Documentary research, vol. 2, pp. 3-45, Sage Publications, London.

Ary, D., Jacobs, L.C., Razavieh, A. \& Sorensen, C., 2006, Introduction to research in education, 7 th edn., Thomson Wadsworth, Belmont.

Ayer, A.J., 1972, Language, truth and logic, Penguin Books, Harmondsworth.

Ayisi, E.O., 1992, An introduction to the study of African culture, East African Education Publishers, Nairobi.

Beyers, B.K., 1988, Developing a thinking skills program, Allyn \& Bacon, Inc., Boston. Bodunrin, P.O., 1981, 'The question of African philosophy', Philosophy 56(216), 161-179.

Broodryk, J., 2002, Ubuntu: Life lessons from Africa, Ubuntu School of Philosophy, Pretoria.

Burns, N. \& Grove, S.K., 2001, The practice of nursing research: Conduct, critique and utilization, 4th edn., W.B. Saunders Company, London.

Department of Education (DoE), 2001, Manifesto on values, education and democracy, Department of Education, Pretoria.

Ellis, R., 1983, 'Philosophic inquiry', Annual Review of Nursing Research 1, 211-228.

Ennis, R.H., 1964, 'A definition of critical thinking', International Reading Association 17(8), 599-612.

Ennis, R.H., 1989, 'Critical thinking and subject specificity: Clarification and needed research', Educational Researcher 18(3), 4-10.

Gall, M.D., Bog, W.R. \& Gall, J.P., 1996, Educational research: An introduction, 6th edn., Longman, New York.

Gratton, P.M., 2003, 'What's in a name? African philosophy in the making', Philosophia Africana 6(2), 61-80.

Gyekye, K., 1995, An essay on African philosophical thought: The Akan conceptual scheme, Temple University Press, Philadelphia.

Gyekye, K., 1997, Tradition and modernity: Philosophical reflections on the African experience, Oxford University Press, Oxford.

Heidegger, M., 1956, What is philosophy?, College \& University Press, New Haven.

Higgs, P. \& Smith, J., 2006, Rethinking our world, 2nd edn., Juta, Cape Town.

Hofstee, E., 2006, Constructing a good dissertation: A practical guide to finishing a Masters, MBA or PhD on schedule, Exactica, Johannesburg.

Holsti, O.R., 1969, Content analysis for the social sciences and humanities, AddisonWesley Publishing Company, London.

Hountondji, P., 1983, African philosophy: Myth and reality, Hutchinson \& Co. publishers Ltd, London.

Letseka, M., 2000, 'African philosophy and educational discourse', in P. Higgs, N.C.G. Vakalisa, T.V. Mda \& N.T. Assie-Lumumba (eds.), pp. 179-193, African voices in education, Juta, Landsdowne. 
Masolo, D.A., 1994, African philosophy in search of identity, Indiana University Press, Bloomington.

McMillan, J.H. \& Schuhmacher, S., 2010, Research in education - Evidence-based enquiry, 7th edn., Pearson, New York.

Mbiti, J.S., 1969, African religions and philosophy, Doubleday, New York.

Mbiti, J.S., 1975, Introduction to African religion, Heinemann, London.

Morrow, W., 1989, Chains of thought: Philosophical essays in South African education Southern Book Publishers, Johannesburg.

Morrow, W., 2007, Learning to teach in South Africa, HSRC Press, Cape Town.

Neuman, W.L., 2006, Social research methods: Qualitative and quantitative approaches, 6th edn., Pearson Education, Inc., Boston.

Nieuwenhuis, J., 2010, 'Introducing qualitative research', in K. Maree (ed.), First steps in research, pp. 47-66, Van Schaik, Pretoria.

Nyamapfene, K.A. \& Letseka, M., 1995, 'Problems of learning among first year students in South African universities', South African Journal of Higher Education students in South
$9(1), 159-167$.

Oruka, H.O., 1990, Sage philosophy: Indigenous thinkers and modern debate on African philosophy, E. J. Bill, Leiden.

Oruka, H.O., 2002, 'Four trends in current African philosophy', in P.H. Coetzee \& A.P.J. Roux (eds.), Philosophy from Africa, 2nd edn., pp. 120-124, Oxford University Press, Cape Town.

Patton, M.Q., 2002, Qualitative research and evaluation methods, 3rd edn., Sage, Thousand Oaks.

Priest, G., 2006, 'What is philosophy?', Philosophy 81, 189-207.
Pring, R., 2007, 'Reclaiming philosophy for educational research', Educational Review 59 (3), 315-330.

Ramose, M.B., 2002, 'The philosophy of ubuntu and ubuntu as a philosophy', in P.H Coetzee \& A.P.J. Roux (eds.), Philosophy from Africa, 2nd edn., pp. 230-238, Oxford University Press, Cape Town.

Ramphele, M., 2001, 'Citizenship challenges for South Africa's young democracy', Daedalus: Journal of American Academy of Arts and Sciences 130(1), 1-17.

Senghor, L.S., 1976, Prose and poetry, ed. \& transl. J. Reed \& C. Wake, Heinemann African Writers Series, Nairobi.

Shutte, A., 1993, Philosophy for Africa, University of Cape Town Press, Cape Town.

Sindane, J., 1994, Ubuntu and nation building, Ubuntu School of Philosophy, Pretoria.

Sindane, J. \& Liebenberg, I., 2000, 'Reconstruction and the reciprocal other: The philosophy and practice of ubuntu and democracy in African society', Politeia philosophy and
$19(3), 46$.

Slonimsky, L. \& Shalem, Y., 2006, 'Pedagogic responsiveness for academic depth', Journal of Education 40, 35-58.

Tempels, P., [1959] 1976, Bantu philosophy, Presence Africain, Paris.

Thomas, R.M., 1998, Conducting educational research: A comparative view, Bergin \& Garvey, London

Venter, E., 2004, 'The notion of ubuntu and communalism in African educational discourse', Studies in Philosophy and Education 23, 149-160.

Waghid, Y., 2004, 'African philosophy of education: Implications for teaching and learning', South African Journal of Higher Education 18(3), 56-64.

Wiredu, K., 1980, Philosophy and an African culture, Cambridge University Press, Cambridge. 